\title{
From Editor's Desk
}

During the past couple of years there have been spate of activities in the realm of building closer professional relationship between IIW and welding fraternities in other countries such as in the USA, UK, Singapore, in keeping with the objectives of our Memorandum and Articles of Association. One such success story has been the signing of MOU on 8th July / 26 August 1995 between the IIW and The American Welding Society (AWS) under the patronage of our previous President, Dr. Placid Rodriguez. In this editorial we will try highlighting areas in the MOU for general information.

In the Premable of the text (MOU) it states "This agreement ....... establishes a cooperative relationship. devoted to advanc s the science, technology, application of Welding" and for "..... exchange of information and knowledge". The members of the two organisations would enjoy the previlege of, (i) attending each other's conferences, educatuonal programmes as if members of the same organisation "except that fees inay be waived by the host society .....". This would benefit our members in the USA and they who would be going over to attend AWS's programme. All publications of one organisation "..... shall be made avallable to members of the other organisation at member's rate". We would also mutually benefit from the supply of ..... one copy of each other's technical-standards, codes, educational texts". Once received thest materials need to be made available at the IIW library for reference work. On the membership issue Members of our Institute, who meet the membership requrements of the other may apply for their membership without need for formal reference, and intiation fees ...", is a boon to our membership in general. Student members of either organisation may be invited to participate in the students' conferences of the other and

the guest society shall be responsible for arrangement of meetings and expences of guest society student members". If this increases accessibility to such conferences so much the better and need we say we welcome it. There are now reciprocal arrangements for publicising each other's ".... conferences and other programmes

if the member organisations so wish. in therr publicatjons and journals. One of the beneficial point gathered is that "each society may publish in its general publications articles or translations of articles appearing in the publications of the other Soclety without obtarning specific permission ...". Additional copies (25) uf each others publication : obtained at a premium 331/3\% discount is useful information for our Branches who have or are thinking of having a library. The two organisations could _ponsor, participate and cooperate in each other's Programme and a written understanding is to prevail between the two organisations for such event.

In paragraph D.I, on "Unrestricted Participation of All Nationals" AW/S endorses the principle of unrestricted participation of citizens of all nations at "International Conference is plausible. In the following sentencce,

the intent for conferences, administered or endorsed by AWS, shall be the commitment... of IIW to secure freedom of citizens of all nations "to enter India for the purpose of attending such a conference"

appears overloaded. Pertinent question could be as to what extent had there been occations, in either of the two colintries, when such restrictions have been impositioned, except perhaps during the periods of state of emt. gency as was indeed there during the World-War 2. The MOU contains host of other areas of mutual interest. In consideration the text of the MOU is published in this issue of IWJ.

In regards to selection of material for publication in IWJ, in general, we adhere to the basics of (1) recelving a text, (ii) assessment of the text (in some cases requiring "wider" scrutiny), (iii) Editors decision, (iv) com munication with author on the decision. Could it be farer then to request for a written text in time for the next issue of the IWJ. The emphasis is on a written text, please!

$\mathrm{Sd} /-$

(Dr P Majumdar)

Editor 